\title{
An Evaluation of Payment for Ecosystem Service models implemented in Areas of Rural Poverty in China, Rwanda, Zimbabwe, and Mexico ${ }^{1}$
}

\begin{abstract}
Mariel Klein ${ }^{2}$
Abstract: Poor communities living in rural areas have complicated and essential relationships to the environment in which they live. Such communities often live in degraded ecosystems where natural disasters and climate change incur systematic and largescale damage to communities. Income earning potential most often comes from agriculture and from ecosystem services, which are gathered or farmed products such as timber, clean water, plant material, and wildlife that are farmed and sold. Driven by survival needs or poor government management, these activities are often practiced using unsustainable methods that cause further harm to degraded landscapes. To combat this phenomenon, and to tackle the exceptionally large goals of improving economic livelihood for rural poor communities while conserving diverse ecosystems, several largescale policy programs have been implemented in multiple developing nations around the world. Most of these programs including components of payment for ecosystem service models (PES), which compensate communities in various ways for harvesting and selling forest products such as timber, water, and wildlife. This paper reviews four such programs: RFFP in China, a wetlands payment for ecosystem services structure in Rwanda, CAMPFIRE in Zimbabwe, and REDD+ in Mexico. It identifies pros and cons of each and begins to make broad recommendations about efficacy of such programs. Recommendations center around ensuring effective land use policy, utilizing communitybased program management, promoting land ownership at a community level, and a balancing of forest conservation and economic activities.
\end{abstract}

Key Words: Conservation programs, rural poverty, livelihood, ecosystem services, community-based management, agriculture

\section{Introduction}

According to the 2014 Multidimensional Poverty Index (MPI), 85\% of impoverished people live in rural areas (Alkire 2014). Poor populations in rural areas have complex, precarious, and essential relationships with the environment in which they live. This is due to the fact that poor, rural communities tend to be more dependent on their natural environment than more economically stable populations and are therefore more vulnerable to environmental changes, whether from global climate change or from local disasters (Eakin and Lemos 2010).

\footnotetext{
${ }^{1}$ Submitted on July 6, 2020. Accepted on July 25, 2020. Last revisions received on August 25, 2020.

2 Johns Hopkins University, Advanced Academic Programs. 1717 Massachusetts Avenue NW, Washington, District of Columbia, USA 20036. E-mail: kleinmariel91@gmail.com .
}

DOI: 10.9784/LEB8(2)Klein.01

Electronically available on August 31, 2020. Mailed on August 31, 2020. 
Poor populations often live in some of the most environmentally degraded and vulnerable areas. This is to the result of being pushed out of wealthier areas as well as increasing urbanization, the frequent need to intensify agriculture, and the use of degrading agricultural practices such as deforestation, overgrazing and soil mining (UNFPA 2001). Such rapidly increasing impoverished populations become some of the most environmentally destructive actors, not only robbing the environment in which current populations reside but robbing future populations who must make do with increasingly barren land (Von Braun and Gatzweiler 2014).

On the other side of the spectrum, rural poor communities are often more intensely impacted by degradation and damage to their environments as a result of natural disasters, invasive species, flood, and drought. This is due to the fact that these communities depend more heavily on the ecological services provided by their environments to survive and maintain their livelihood (Tallis et al. 2011). Access to land is another issue, with many native and indigenous populations living on land that has changed hands multiple times, is owned under tenuous land rights agreements, or was acquired by the government in exchange for producing from the land (World Bank 2002).

The complicated quagmire of rural poverty is that when natural resources are depleted and used unsustainably, they contribute to poverty, but also the unsustainable practices of poor populations contribute to environmental degradation. This push and pull often affects the survival of these populations and can also 'trap' populations in poverty (Pattanayak and Sills 2001). Poor populations are often forced by their dire circumstances to prioritize short-term benefits, which tend to involve environmentally degrading practices, over longterm gains, which could be achieved through more sustainable practices (Brundtland 1984). To attempt to mitigate or completely solve these problems, concurrent thoughts, and action in the two areas of poverty reduction and environmental degradation need to occur (Von Braun and Gatzweiler 2014).

Agriculture and ecosystem services are two of the largest sources of livelihood and financial gain for poor, rural populations. Agriculture is a key sector in rural areas. It serves, according to some estimates, as a main income source for $86 \%$ of rural populations worldwide. Agriculture provides employment for 1.3 billion small farmers and landless workers (Sikor 2014). Globally and consistently, agriculture above other economic activities is the most effective means of reducing poverty (Sikor 2014).

The Millennium Ecosystem Assessment defines an ecosystem service as "any positive benefit that wildlife or ecosystems provide to people" (Reid et al. 2005 p. 5). Such services include water and air quality, fiber and fuel sources, and biological diversity (Reid et al. 2005). Each of these ecosystem services are linked to an aspect of human well-being, which are especially crucial in areas of rural poverty, where subsistence is reliant on the land. These ecosystem services are 
often regulated through land rights and Payment for Ecosystem Services (PES) structures.

It is clear that the relationship between rural poverty and ecological health is complicated and inextricably interwoven. While the potential to reduce poverty and improve forest conservation does exist, achieving both goals requires tremendous effort on the part of local governments, policymakers, and local leaders.

This paper will evaluate four such programs; the Returning Farmland to Forests programs in rural China, Ecosystem Services models in Rwanda, CAMPFIRE in Zimbabwe, and REDD+ schemes in Mexico. The goals of this paper are to review PES structures in these four countries and related programs, recognize pressures on such structures, and define pros and cons of each program. This paper will then seek to make general recommendations for methods of improving the efficacy of such programs and continuing development of other such programs.

\section{Methods}

This paper was completed by conducting a thorough literature review to include as many primary sources as possible, including classic papers produced on this topic as well as new and cutting-edge studies. Classic papers were determined through a cross-referencing process of older articles and newer publications to identify the most widely referenced studies. Articles were found using Google Scholar searches aimed at identifying ecosystem service programs in diverse areas of the world. Attention was made to include studies performed onsite, in the countries of interest, and those studies that included concrete recommendations and conclusive data. The selection of the four countries included in this paper was made due to the extensive literature around the said programs, as well as their collective representation of the diversity of ecosystem service programs. The countries were additionally selected due to their long operationalization tenure.

\section{Returning Farmlands to Forest Programs in China}

Poverty in China represents a compelling success story in that it is one of only several developing countries that has made significant progress in bringing residents out of extreme poverty for the past 25 years (Fan 2004). In 1978, the country had about 250 million residents living below the poverty line, which improved significantly to about 30 million in the year 2000 (Fan 2004). Government investment in rural agriculture proved crucial in this effort. Government took on the role of overseeing the decollectivizing of agricultural production and created a market for the sale of surplus product by farmers. Innovative and efficient agricultural infrastructure was also allowed to be built (Fan 2004). Through this government action, China increased the annual growth 
rate of agriculture from an average of $2.5 \%$ from $1950-1970$ to $7.4 \%$ by the year 1980 (Zhang 2006).

Some studies suggest, however, that this impressive speed of poverty reduction has slowed since the 1990's, in part to rising income inequality. Such studies include a 1999 study by Khan (1999), and a 2004 study by Ravallion and Chen (2004). Zhang in their 2006 study refutes suggestions that a return to agriculture could be a way to return to the incredible poverty reduction progress of the 1980's, stating using that China's economy has changed dramatically from the 1980's and cannot support a larger share of China's economy looking to source its success from agriculture (Zhang 2006).

The Returning Farmland to Forests Program (RFFP) was initiated in 1999 and represents an attempt by China's government to continue the dramatic decrease in levels of rural poverty not through agricultural intensification, but by converting farmland to forests, restoring native vegetation, and improving the quality of forest management ( $\mathrm{Li} \mathrm{2020)}$. This is accomplished by regularly paying poor rural landowners to convert the land through tree plantings and afforestation (Zinda 2019) ultimately creating wealth and improving livelihood, as well as achieving ecological goals of improving biodiversity, controlling erosion, and sequestering carbon (Trac 2017, Zinda 2019). Li's livelihood to forest product framework demonstrates those capital inputs needed to influence livelihood outcomes (Figure 1).

Farmers in an RFFP are encouraged to consider converting their farmland to one of several types of forest; an economic forest, which can be an orchard or plantation that primarily produces "fruits, nuts, edible oils, spices, medicinal plants or derivatives, and industrial raw materials" (Trac 2017) or an ecological forest which can produce ecosystem services such as timber, fuel wood, biodiversity production and conservation, and national defense (Trac 2017).

By converting farmland to forest, the RFFP aims to not only compensate exfarmers for converting the land but also aims to change the nature of some rural labor from farm work to work outside of the farm. This would, in theory, enable sustainable economic development by diversifying the amount of income-earning opportunities and by supplementing agricultural activities during periods when productivity is reduced, such as a drought or flood.

The RFFP has to date been implemented in multiple regions in China, including the Sichuan and Yunnan provinces (Figure 3) and has been hailed as "the world's largest and most successful Payment for Ecosystem Services program" (Ying and Yao 2014). It has been a major promotor in the impressive increase in forest cover in China. In 1960, forest cover represented about $8 \%$ of the total landscape. By 2017, while over $21 \%$ of total land cover was represented by forest (Trac 2017). Since 1999, China, through the RFFP, has replaced cropland with trees across 293,700 acres, and paid 32 million households about $\$ 52$ million in government investments (Zinda 2019). 


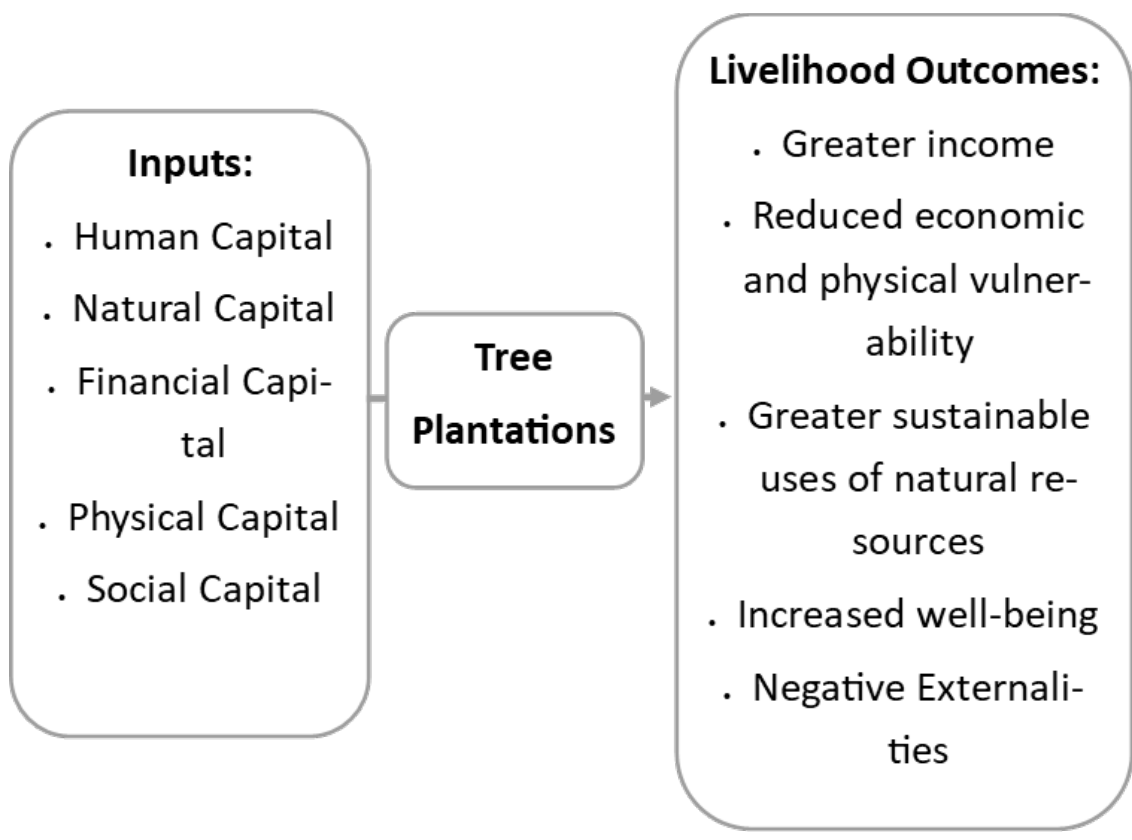

Figure 1. Livelihood framework of tree plantations. Adapted from Li (2020).

An evaluative RFFP project was implemented in Southwest China in Weixi Lisu County, Yunnan Province, (Li 2020) which is located in the Hengduan mountain range. The county implemented their RFFP in 2001.

Results from the RFFP in the Weixi Lisu county found positive ecological benefits. In comparison to non-RFFP villages, the "density, diameter at breast height, coverage, and biomass of the tree layer in the communities with RFFP were all higher, while the height and species diversity were lower" (Li 2020). In addition, the soil acidity remained the same in both RFFP and non RFFP communities, and the forest quality index indicated only a marginal improvement in RFFP communities. The best economic returns came from plantings where fruit and nut trees were mixed in with industrial use trees, such as rubber trees, rather than monoculture planting (Li 2020).

RFFP projects evaluated in other provinces, however, found several ecological issues with RFFP programs, such as the fact that some planted tree species were non-native or inappropriate species, and some planting of trees occurred in areas that would have been better ecologically and productively left as meadows or grasslands. In some areas where tree cover expanded, the cover was mostly dominated by monoculture plantations, thereby not contributing to the overall ecological health of the area (Zinda 2019). 


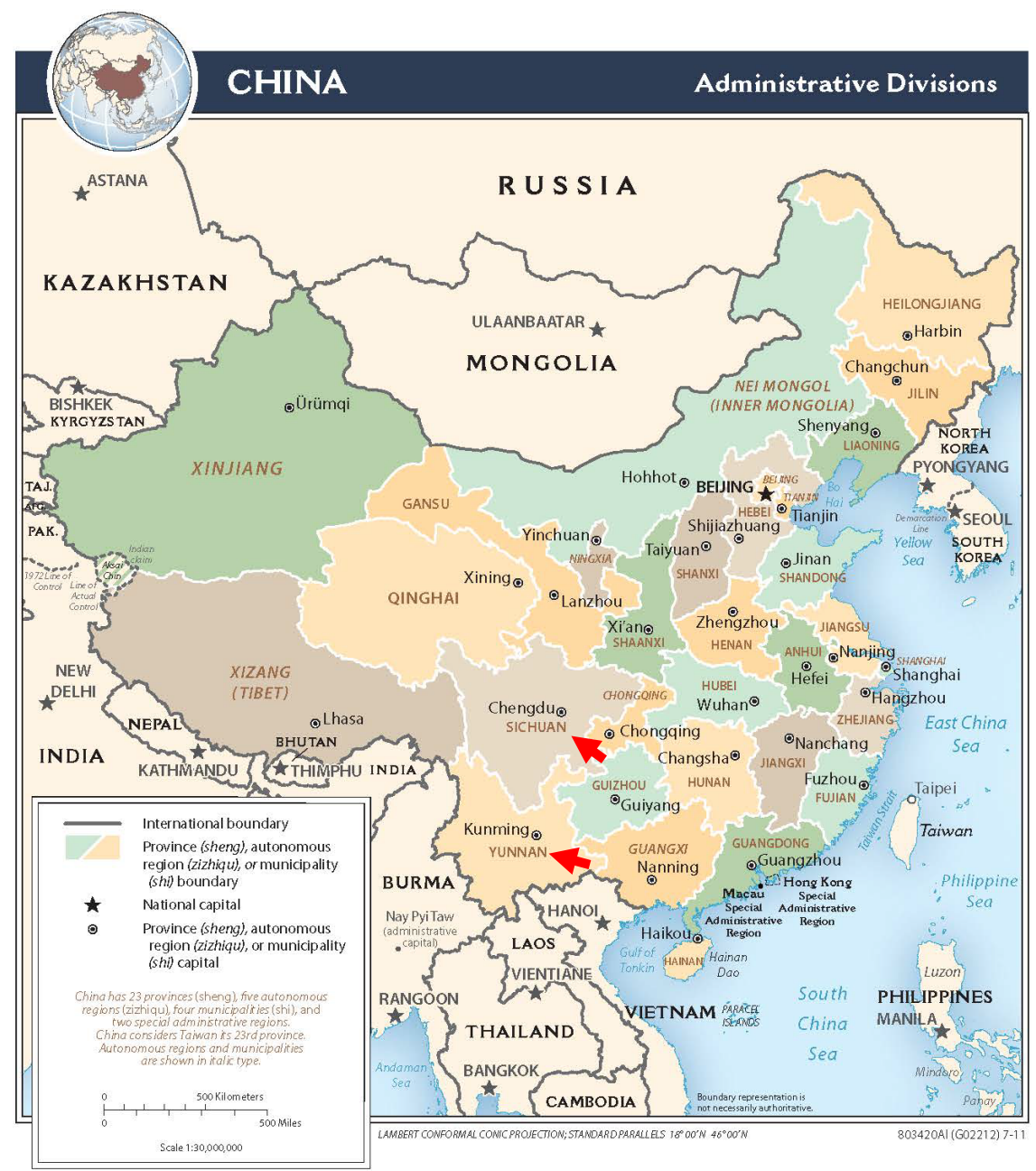

Figure 2. Sichuan and Yunnan Provinces, China. Map courtesy of The University of Texas at Austin. https://legacy.lib.utexas.edu/maps/china.html . The arrows point to the Chinese provinces of Sichuan and Yunnan.

Researchers hypothesized that the RFFP would result in the proliferation of non-farming labor due to a decrease in total farmland area which would cause farmers to implement novel methods of preserving their livelihood. However, results showed that the RFFP communities showed only slightly smaller proportions of households engaged in non-farming labor ( $\mathrm{Li}$ 2020). Results from the Weixi Lisu county additionally found that farmers who were most successful in 
both RFFP participation and in securing well-paying off-farm work tended to be younger, more educated farmers, thereby creating an equity gap that left older, less educated farmers either struggling within RFFP programs or refusing to participate (Gao 2020).

Meta- evaluation of several RFFP programs revealed issues related to program management and measurements of success. In the Juizhaigou region, for example, local governments failed to fully realize farmers' spectrum of needs and failed to coordinate effectively among government agencies. They also relied on overly simplistic targets to evaluate programs and were ineffective in monitoring personnel and equipment (Trac 2017). These issues were not unique to the Juizhaigou region, and widely contributed to reporting discrepancies that dominated many RFFP evaluations (Trac 2017). For example, the Chinese government reports hectares of reforestation and diversity by county, which tends to paint a rosier picture. Researchers working with community-level data found much less successful results related to biodiversity and forest health when collecting data at the community level (Trac 2017).

Conservation results varied wildly between RFFP-implementing communities, often even between communities in the same township or county, fueled mostly by cultural differences that influenced receptiveness to the program, and evaluations of livelihood improvements, which produced tree stands of wildly different quality (Zinda 2019). Zinda in their 2019 study suggests that it is extremely difficult to accurately attribute successful reforestation efforts to an RFFP program due to the varied presence of environmental and social factors such as independent retirement of farmland, natural migration flows of people from rural to urban areas in search of work, and orchard planting, which technically represents tree planting but does not constitute reforestation (Zinda 2019).

Other management issues include the fact that the Chinese government, in its quest for success, emphasized quick, measurable, and visible results, rather than investing more time and effort into parsing out best practices by region and community (Brandt et al. 2012). According to a 2020 analysis by Gao et al., a reason for this is that in many communities, the added value of replacing croplands with even economic forests was not enough to fully replace the revenue generated by primary farming. This reduced the budgetary revenues of those local governments and caused local officials to either become demotivated to participate in the RFFP, or to convert cropland unsuitable for forest conversion (Gao 2020).

Government oversight and accountability caused other issues in some regions where participants were not adequately paid for their role 
in forest management. In some situations, local officials who were appointed to manage the programs acted in their own self-interests and used the collective action around the RFFP to benefit their own business enterprises (Zinda 2019). Other officials struggled with managing the vast array of collective goods and attempted to prioritize outcomes for the collective, causing issues among individuals (Zinda 2019).

Ultimately, while RFFP projects do increase tree cover and contribute to reforestation, effort and money could be spent in other, less labor-intensive methods of forest maintenance, such as installing solar water heaters which would reduce reliance on firewood (DeFries and Pandey 2010). In addition to being somewhat inefficient, RFFP programs tend to apply a "panacea effect," in that they are attempting to increase forest cover using generalized tactics and measures, which can leave communities worse off than they were prior to the program, or at least not receiving all of the potential benefits available from RFFP programs (Trac 2017).

\section{Payment for Ecosystem Services in Rwanda}

In Rwanda (Figure 3), high poverty rates in the years since its brutal 1994 genocide has remained pervasive and well-documented. As of $2010 / 11$ (the most recent living standards survey), $45 \%$ of the country's total population exists below the national poverty line, and $24 \%$ are classified as 'extremely' poor (live below the national food poverty line (Christiaensen and Demery 2007). Looking at poor populations in rural areas, about half of those individuals live below the national poverty line, compared to only about $22 \%$ of the urban population (Christiaensen and Demery 2007). Agriculture makes up the largest economic sector; over $80 \%$ of poor households rely on it as their main source of income and/or subsistence (Rosa et al. 2017).

Looking at Rwanda's ecological and climactic location, it is clear why it seems to be fighting an uphill battle to escape from poverty. It is a small, landlocked country located in the southern equatorial area of Africa (Willetts 2008). It has little natural resources and arable land (only about $5.5 \%$ of total land area is suitable for agriculture) (Knausenberger 1996). It boasts consistently high population growth but limited human capital (Willetts 2008). It faces looming consequences of climate change, the two largest being water related; prolonged seasonal drought and decreasing levels of total precipitation during rainy seasons (Willetts 2008). Rwanda also faces declining levels of biodiversity, predominantly in native plant and fish populations (Clay et al. 1996, Christiaensen and Demery 2007). 


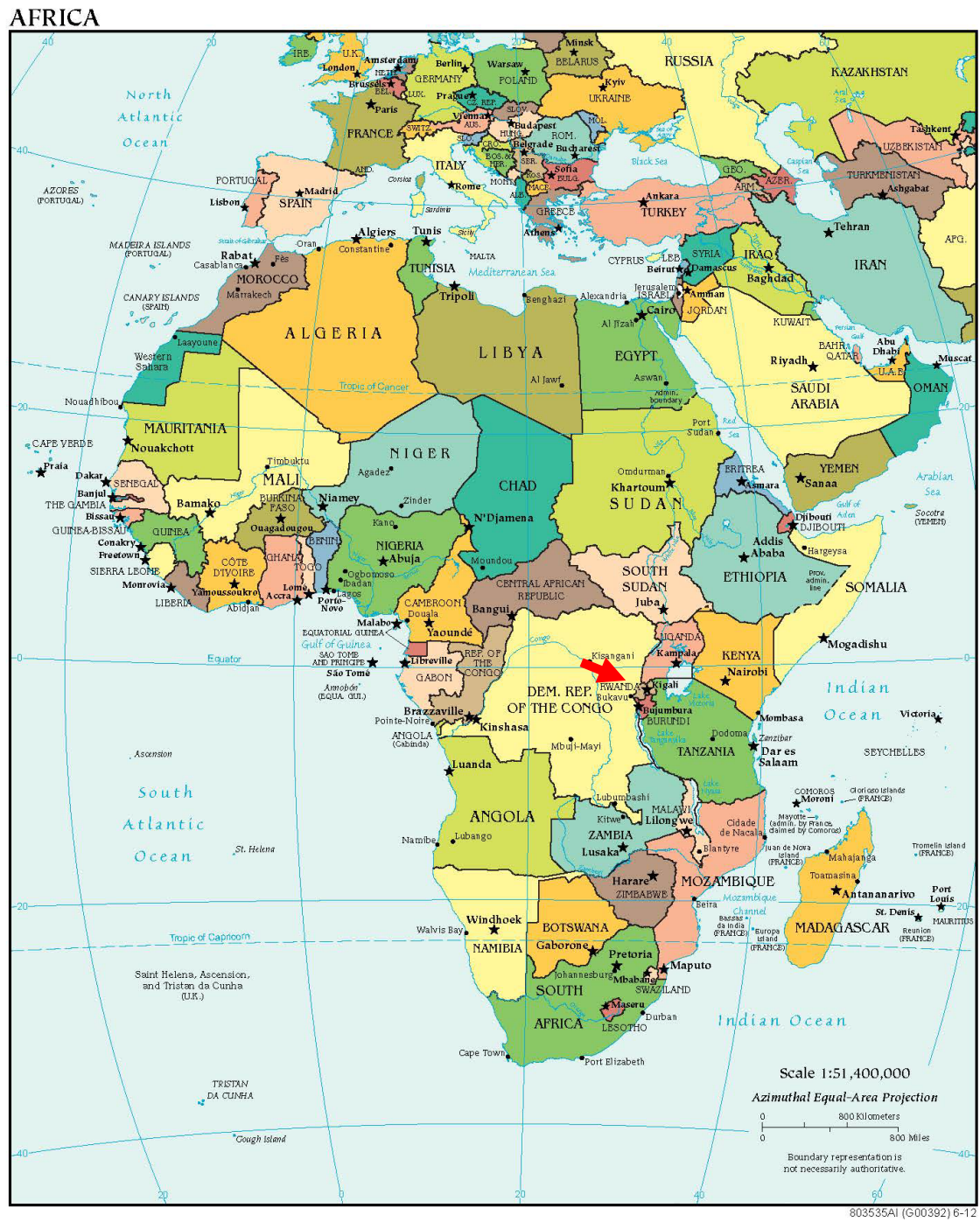

Figure 3. Country of Rwanda, Africa. Map courtesy of University of Texas at Austin. https://legacy.lib.utexas.edu/maps/africa/africa pol 2012.pdf . The red arrow points to the country of Rwanda.

Payment for Ecosystem Services models (PES) were introduced into Rwandan landscapes as a way to help poor subsistence farmers, who rely heavily on ecosystem services such as firewood, raw materials, and plant fibers (Karangwa 2011). PES models seek to translate ecosystem services directly into economic benefit by paying poor farmers and communities directly to sustainably 
manage their land to provide valuable services (Willetts 2008). PES models also help quantify real losses due to the loss of an ecosystem service. Such direct connections are found in Figure 4, which was determined through extensive surveys of members from eight rural Rwandan villages (Dawson 2015).

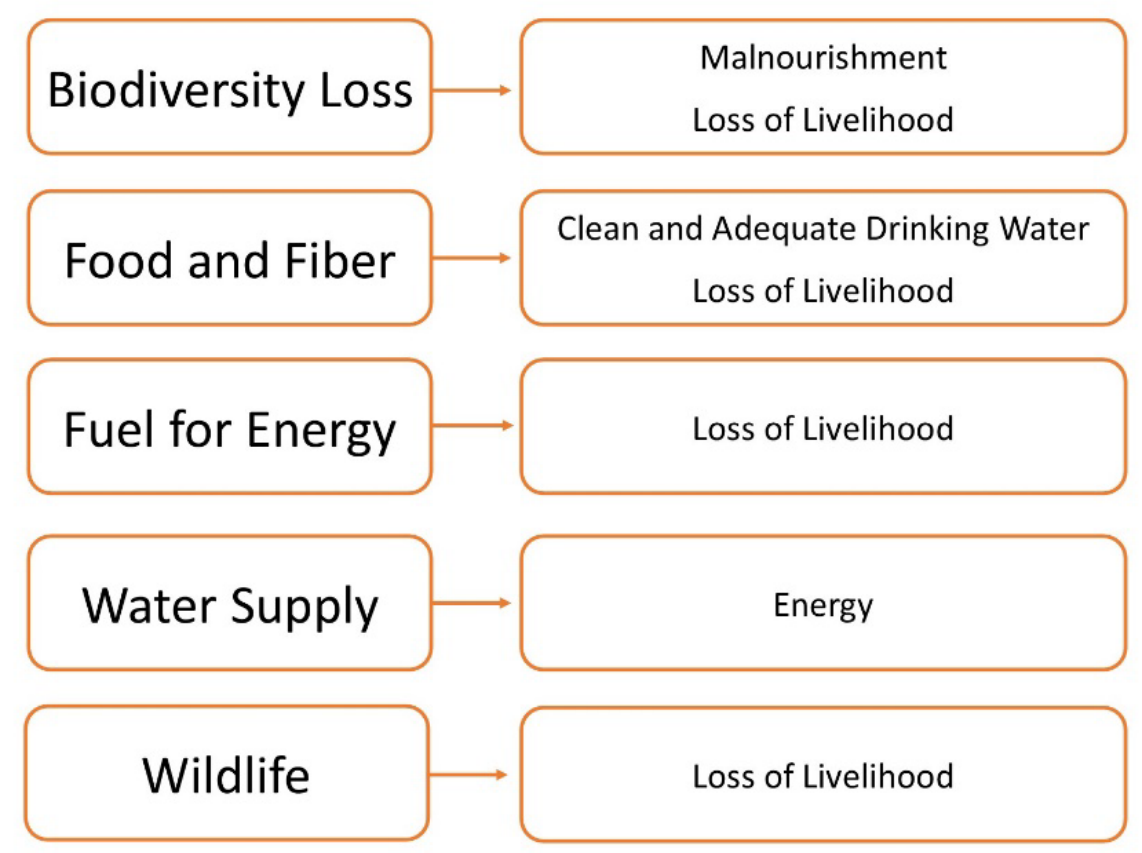

Figure 4. Stressed services and resulting effects on aspects of human well-being. Modified from Clay et al (1996).

Operating such PES structures in Rwanda has proven difficult from inception. Most PES models came out of Latin America, where they were used to subsidize wealthy landowners to better steward their land (Karangwa 2011). This is not the structure in place in Rwanda, where PES is used to provide livelihood for poor farmers. Many PES structures in Rwanda began their focus on one of three topics: carbon sequestration, water, and biodiversity (Karangwa 2011). This paper will case study a PES scheme focused on water management in the Rugezi wetlands conducted by Willetts in 2011.

The Rugezi wetlands are located in the northern highlands of the most northern province of Rwanda and total 6,735 hectares (Willetts 2008). They are a highland peat bog and therefore determine the quality of the gravitational water flow that supplies the Mukungwa River, Lake Bulera, and Lake Ruhondo; two of the country's deepest lakes (Willetts 2008). They also play a large role in the country's production of hydropower (Willetts 2008). 
This PES structure becomes complicated in that the wetlands have two large competing values; they are a community resource, and also a source of national energy generation. This creates a conflict in water users, as upland communities want improved water quality for consumption and downstream users want increased flow for energy production (Willetts 2008). Upstream subsistence users have no additional source of income or livelihood other than the wetlands, while the downstream users have alternatives (Willetts 2008). The wetlands supply other ecosystem services, such as medicinal plants, fuel biomass, stabilizing river banks, fish spawning grounds, and migratory bird habitats (Willetts 2008).

Another challenge to this PES comes from the country's environmental policy structure, which does not currently penalize or require environmental impact assessments for the private sector (Willetts 2008). Feedback mechanisms to the government are weak in that climate change issues are controlled by the Ministry of Infrastructure (Willetts 2008). Without correct government support or design, a PES could suffer by confusing conservation objectives with policy transition incentives, but the opposite could also be true. Governmental control plays another huge role in the issue of land tenure, which is a massive limiting factor on PES structures across the globe. Rwanda lacks a government land registration system, leaving pockets of ownerless land essentially being squatted on by poor farmers. This boosts costs of PES implementation in that the first step in the program would need to include documenting all of those pockets of land. To attempt to overcome this issue, however, a PES system could transfer land rights to poor communities as a form of compensation (Willetts 2008).

In the case of the Rugezi wetlands PES, extensive surveys revealed that the PES would be crucial to achieve large capacity building goals, such as improved environmental management, strong local economies, and improved social capital (Willetts 2008). Stakeholders passionately believe that, for example, without a PES, conflicts between the hydropower utility and wetland inhabitants would not abate and would impede any environmental management capabilities wished by any conservation group (Willetts 2008).

Ultimately, the study concluded that the potential for this PES was mostly strong, but the program needed additional cost-benefit data before beginning. It also needed a correct payment mechanism, an issue that plagues other global PES systems. A correct payment mechanism would be pro-poor, realistic, and would be based on mutual definitions of resource use (Willetts 2008). Issues could arise in the following instances.

An improperly designed system could actually increase inequity and poverty. The Rwandan government, if it became unstable, would cause massive issues for the continuity and reliability of the program, and of course the issue of land ownership could continue to plague the program if not discussed and implemented correctly (Willetts 2008).

Conservation-wise, the study posited that the achieving of hydrologic goals is uncertain in that it could move large swaths of people from the watershed to 
improve water quality, but that would be a costly effort both socially and financially (Willetts 2008). A hydrologic timeline would need to be studied, evaluated, and carefully implemented to ensure that appropriate steps were being taken in pre-determined intervals.

\section{CAMPFIRE in Zimbabwe}

The CAMPFIRE (Communal Areas Management Program for Indigenous Resources, Logan and Moseley 2002) program is a PES program similarly structured to REDD+ in Mexico (to be discussed later in this paper) and Rwanda's PES. It operates slightly differently in that the ecosystem service being quantified and incentivized is the management of wildlife. The two programs also differ in that CAMPFIRE was not intended to provide the sole means of livelihood for participants, but rather a supplemental source of income. CAMPFIRE participation at the household and ward level has not always been voluntary, unlike most PES programs (Frost and Bond 2008).

CAMPFIRE is based in Zimbabwe (see Figure 5). It was established in 1982 through an amendment to the Parks and Wildlife Act of 1975 that designated Zimbabwe's Rural District Councils (RDC) as the overseeing authority over wildlife in communal areas (Murombedzi 1999). In 1989, management of the program was transferred to the Department of National Parks and Wildlife Management, and sponsorship was added from the World Wildlife Fund and several local entities (Logan and Moseley 2002).

The original intent of the program was to tackle issues of wildlife management in the country of Zimbabwe while reducing poverty. This would be accomplished by classifying the management of designated wildlife as an ecosystem service and providing shares of revenue to local communities who would then manage the wildlife that appeared on their land. This would 'meld' both the ecological and economic goals of the region, transform the control structure from state to communal ownership, and designate wildlife management within this new control structure as a way to both increase food production and reduce poverty (Logan and Moseley 2002).

Specific activities related to the management of wildlife and associated proportions of revenue can be found in Figure 6. As can be inferred from the diagram, all sources of revenue associated with 'management' of wildlife involve ensuring their success until they can be killed or culled by tourists or game managers.

CAMPFIRE has been celebrated as one of the most successful programs of its genre due to its perceived management allowance at the local level (Logan and Moseley 2002). However, as was the case in evaluations of similar PES structures such as REDD+, CAMPFIRE is not without fundamental issues that have kept it from achieving greater success and has garnered many critics. 


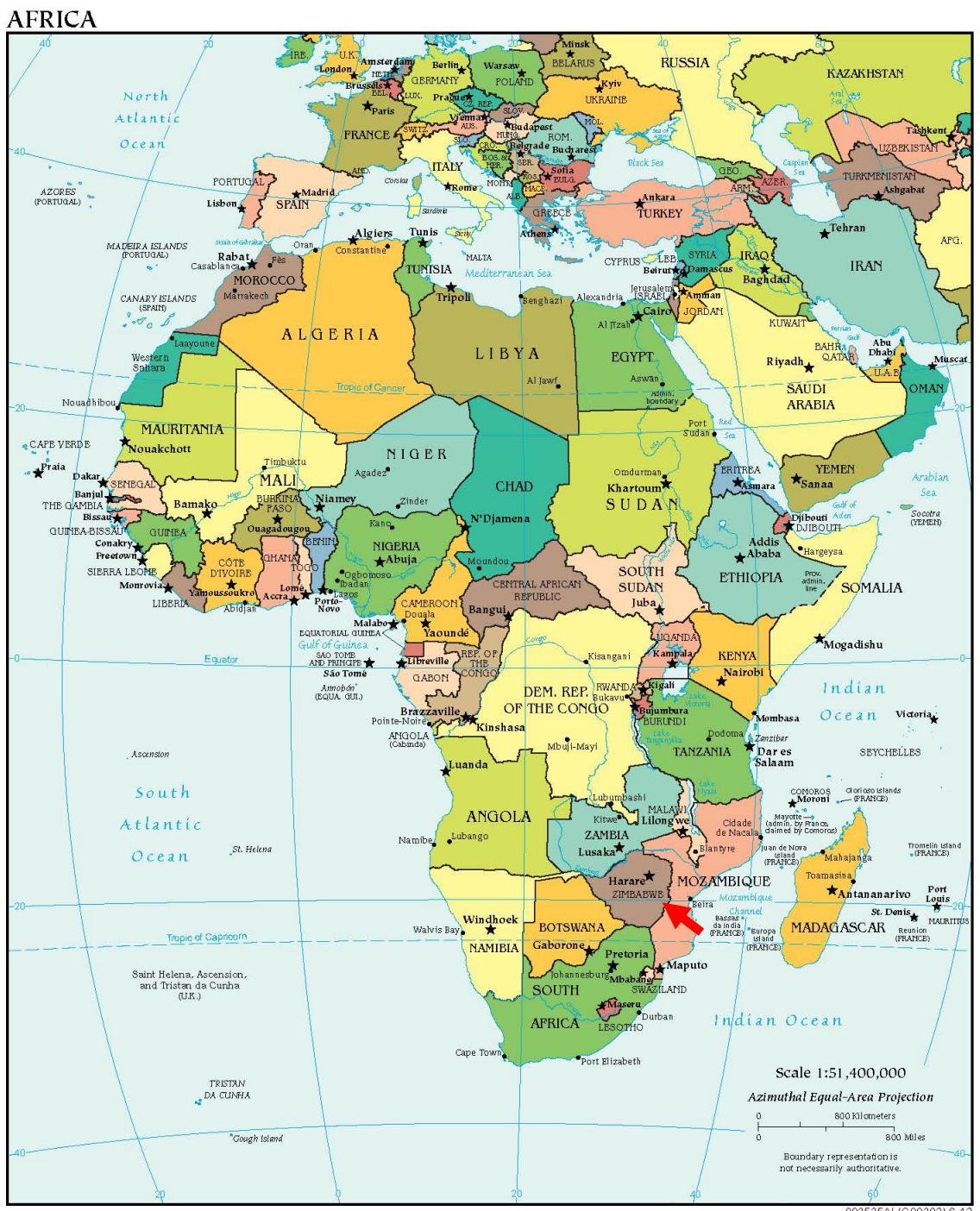

Figure 5. Country of Zimbabwe, Africa. Map courtesy of University of Texas at Austin. https://legacy.lib.utexas.edu/maps/africa/africa_pol_2012.pdf. The red arrow points to the country of Zimbabwe.

The first set of issues stem from the fact that, like similar programs, management and subsequent revenue is not managed directly by the producer communities, but mostly by local authorities (Murombedzi 1999). Producer communities may enjoy a determined share of the revenue dependent on the 
wildlife activity performed, although that share is diminished by required tax payments to RDCs. The producer communities, however, have little to no control over the actual management of the wildlife, and are thereby removed from actual decision-making authority in regard to the use of their own lands. In addition, producer communities are barred from creating and selling additional goods and services to the wildlife industry, which would allow for additional revenue generation. They also have no say in the equity of the utilization of the wildlife on their lands (Murombedzi 1999).

\begin{tabular}{|c|c|}
\hline Revenue Generating Activity & Description \\
\hline Trophy Hunting & $\begin{array}{l}\text { Provides the highest revenue proportion. Trophy } \\
\text { hunters are willing to pay higher fees and re- } \\
\text { quire less infrastructure than other types of } \\
\text { tourists }\end{array}$ \\
\hline Nature Tourism & Second highest revenue proportions, but by a lot \\
\hline Harvesting Natural Products & $\begin{array}{l}\text { Harvest and selling of products such as croco- } \\
\text { dile, timber, and river sand. Some ivory and skin } \\
\text { is sold from so-called "problem animals." }\end{array}$ \\
\hline Live Animal Sales & $\begin{array}{l}\text { An occasional source of revenue. Animals to be } \\
\text { sold include antelope. }\end{array}$ \\
\hline Meat Cropping & $\begin{array}{l}\text { Little to no available revenue from this source. } \\
\text { Involves culling proportions of prey such as im- } \\
\text { palas and selling skins and other products. }\end{array}$ \\
\hline
\end{tabular}

Figure 6. CAMPFIRE revenue generating activities. Adapted from Logan and Moseley (2002).

Local authorities in many cases did not provide adequate training or information on the specifics of the CAMPFIRE program to producer communities, leading to mistrust of the program's goals, the government officials who manage it, and the wildlife itself (Murphee 2014). In fact, multiple field studies have concluded that as a result of these poor management practices, producer communities do not see the management of wildlife as a joint venture but rather as a decision made by the RDCs and the government (Murombedzi 1999).

Other issues stem from the colonizing intent and control of the program itself; Logan and Moseley in their 2002 paper state that "the view that the poor may be their own worst environmental enemies undergirds" CAMPFIRE goals (Logan and Moseley 2002, p. 3). It is known, from analysis of similar programs and a broad understanding of the complicated dynamic between rural poor populations 
and their environment, that this is a generalized and often untrue statement to make. Therefore, to build the goals of the CAMPFIRE program from such shaky ground is to set the communal intent of the program off to a disingenuous start. Many communities saw their nutrition degrade as they were now being denied the ability to hunt the wildlife on their land, as it was earmarked for farming by tourists and controlled by the government (Logan and Moseley 2002).

A third set of issues arise out of the competing interest of agricultural expansion, which often serves as a more reliable and complete source of income for poor rural populations, and the maintenance of wildlife.

CAMPFIRE officials spent considerable time during program development attempting to convince participants that wildlife management was actually an economic asset and that it would not interfere with agricultural production. This was often a difficult concept to believe since both agriculture and wildlife would vie for the same scarce resources such as arable land and water (Logan and Moseley 2002). Indeed, wildlife often destroyed crops, and the RDC's lacked the funds to be able to sufficiently compensate participants for the damage, leading to a reduced standard of living for those participants (Logan and Moseley 2002). Because agriculture had been such a widespread source of livelihood for rural communities, they, even during participation in CAMPFIRE, continued to invest their revenue shares from CAMPFIRE back into agriculture rather than attempting to improve wildlife management. Often, they invested back into methods of agricultural productivity that remained incompatible with the preferred management of wildlife (Murombedzi 1999).

Throughout the CAMPFIRE program, the highest revenue shares were generally to be made in areas with the lowest human populations due to the correlation with higher wildlife populations. There is a strong correlation, however between areas of low human density, ecological or climate constraints, and inadequate infrastructure that results in low agricultural potential (Murombedzi 1999). A community looking to maximize its income from CAMPFIRE would therefore have to consider residing in an area that affords them little other opportunities other than wildlife management.

A last issue came after the inception of the program when it became clear that the actual management of the wildlife was trickier than anticipated. Wildlife does not understand or obey district or municipal boundaries, and so community benefit and responsibility for management of the animals grew in inequity. Animals move, and so some communities bore the ecological brunt of animal grazing. The animal would then move on to another district where it would be hunted or farmed, leaving the now environmentally degraded community with no revenue to show for the adverse impacts on their land (Logan and Moseley 2002). In addition to the messiness of wildlife boundaries, human boundaries in many of the rural districts also proved semi-permeable and constantly in flux. In some areas, communities were clustered within other communities, and physical 
borders often shifted due to differing criteria, making the distribution of revenue for management activities difficult (Logan and Moseley 2002).

Several texts such as Murombedzi's 1999 study point to the fact that the issues mentioned above did not always plague CAMPFIRE. In fact, in the first several years after its inception, the program worked well in many areas. This was partially due to it being a novel program with a refreshing bottom-up management structure focused on autonomy and community response (Murombedzi 1999). In some communities it did in fact renew an appreciation for the value of the wildlife present on the land. Its increased tourist hunting reduced the amount of complaints about "problem" animals and allowed communities to rely on the revenue from wildlife during lean agricultural times such as during drought. The increase in household revenues led to a multitude of community-funded development in schools and clinics, and conservation practices improved (Murphee 2014).

The program itself grew in leaps and bounds; in 1989, its first year in full operation, it hosted 15 participatory communities and 9000 households; by 1996 that number exploded to a total of 185 communities and 200,000 households. Household benefits during that time increased from $\$ 44$ to $\$ 84$ (ZWL), and USAID disbursements increased from about $\$ 300,000$ to almost $\$ 2 \mathrm{M}$ (USD) (Logan and Moseley 2002). After 1996, politics become a crucial consideration in the success of CAMPFIRE. A case study by German et al. looked at CAMPFIRE management and results pre-and post the year 2000. The year 2000 represents the year in which the ZANU-PF party was defeated for the first time. After this defeat, commercial farms were invaded en masse as an act of revenge against those who the party believed to have supported the opposition, as well as to divert attention from the fact that the country's economy was dropping quickly (German et al. 2009).

This political shift affected CAMPFIRE in a variety of ways, but all of them served to degrade the program rather than improve it. Pre-2000, land management through CAMPFIRE was prospering; multiple wildlife corridors existed with successful infrastructure support, and institutional support for wildlife management was strong. A "problem animal reporting system" was instituted by the World Wildlife Fund in multiple states (Mapedza 2009, p. 9).

Post-2000, however, supporters of the new ruling party attempted to undermine the previous administration through illegal hunting practices, and support for the institutional infrastructure of those wildlife corridors collapsed. As a result, support for CAMPFIRE communities dropped (Mapedza 2009). Dividends paid out to producer communities also dramatically declined after the year 2000. Revenue trends from the year 1991 to 2009 indicated that of the total revenue received by the state of Nenyunga, 95\% of it was received from 1991 to 1999. In 2003, the worst year for dividends, a measly $\$ 117$ check to the state of Nenyunga was not even received by the state, and it was revealed that the councilor in charge failed to cash it (Mapedza 2009). This decline in revenue generation, coupled with a congruent decline in management resulted in the 
CAMPFIRE program largely being hijacked in many states for the personal gain of some government leaders and councilors (Mapedza 2009). Another reason for declining support during this same time period was the withdrawal of support funds by the United States Agency for International Development (Tchakatumba 2019).

A last issue with the CAMPFIRE program is the lack of research and information on the program's effect on the ecological and physical health of the wildlife populations being managed through the program. Many of the program's defined revenue streams result from the culling, killing, or poaching of wildlife. Other revenue streams come from the killing of 'problem animals' which are most often marked as such after negative encounters with humans, many of those encounters occurring due to human encroachment on the animal's territory. This is indicative of larger issues, namely identifying natural territories and incorporating community planning with those territories in mind. According to a 1999 study performed by Tchakatumba, instances of human-wildlife conflict did decrease in the years before 2000 but increased after that time. Instances of poaching followed a similar pattern (Tchakatumba 2019). This can indicate that the program, when properly funded and managed, has a positive effect on humanwildlife interactions.

The general consensus about CAMPFIRE is not that it is a lost program that deserves abandonment (Manyena et al. 2013). In fact, Tchakatumba's study revealed that the majority of interviewed households wanted to continue the program, despite the country being in an economic recession (Tchakatumba 2019). It is clear, however, that it could benefit from largescale policy and management interventions. Suggestions to that extent include:

1. Creating a direct link between safari operators and other actors directly involved with the revenue-generating activities and the producer communities, thereby eliminating the need for revenue to flow through the government, and decreasing the opportunity for corruption and revenue theft by government actors (Mapedza 2009).

2. Establishment of a "watchdog group" that would monitor actions of CAMPFIRE and government officials to ensure that payments were actually reaching the producer communities (Manyena et al. 2013).

3. Increased time, effort, and money dedicated to planning and developing additional resources for producer communities, who have felt largely neglected by the program for many years (Manyena et al. 2013). This should include opportunities to empower producer communities to be included in decision making at a higher, institutional level (Tchakatumba 2019). 


\section{REDD+ in Mexico}

Land rights are a major consideration of any conservation/biodiversity effort in an area characterized by a majority rural poor population, and REDD+ programs in Mexico (see Figure 7) provide an example of how to leverage land rights in an attempt to facilitate policy.

Mexico's communal land rights model is baked into its history, stemming from the Mexican Revolution of 1910. It was formalized in 1992 along with broad constitutional reforms (Cronkleton 2011). The communal rights model had its struggles through history, but emerged as the preferred model to host REDD + and other communal forestry management programs due to its multi-scale governance model, which can support local, national, and international levels of governance, thereby providing both community-level program management as well as overarching oversight and funding (Cronkleton 2011). Other land rights models have come and gone throughout Latin American such as indigenous territories and extractive reserves, but in both models the state retains alienation rights to lands, rendering them eventually privatized (Corbera 2011).

REDD+ stands for "efforts to reduce emissions from deforestation and degradation, foster conservation and sustainable management of forests, and enhancement of forest carbon stocks" (Thompson 2011, p. 100). It is a mechanism to that directly pays both forest owners and forest users for their efforts in reducing deforestation and improving forest management practices (Thompson 2011). REDD+ is one model within the Payment for Ecosystems (PES) model, which represent programs that aim to provide local incentives for emission reduction by reducing deforestation and degradation as well as aim to improve carbon stocks. In a PES scheme, parties who provide environmental service products receive direct payments when sustainable and maintainable land use practices are successfully adopted (Mahanty 2013).

REDD+ also represents a Community Forest Management (CFM) program, which defines a class of programs in which forest resources are managed by selfdefined communities, or by community groups that organize under collective rights or rules (Cronkleton 2011). CFMs have been largely successful in Latin American countries, likely due to the high level of democracy in many of those nations, and since many Latin American countries are characterized by communal land rights and community-based governance (Cronkleton 2011).

REDD+ policies aim to affect change by encouraging voluntary community participation in sustainable forest management rather than forcing state policies to manage use activities. REDD+ implementation in Mexico made a lot of sense from the beginning in that its communal land rights agreements lent itself to communal forest management, it already had an active, 10- year old PES program for water and biodiversity, and it initiated a national forest inventory in 2004, which provided valuable data on forest health (Borrego 2014). 


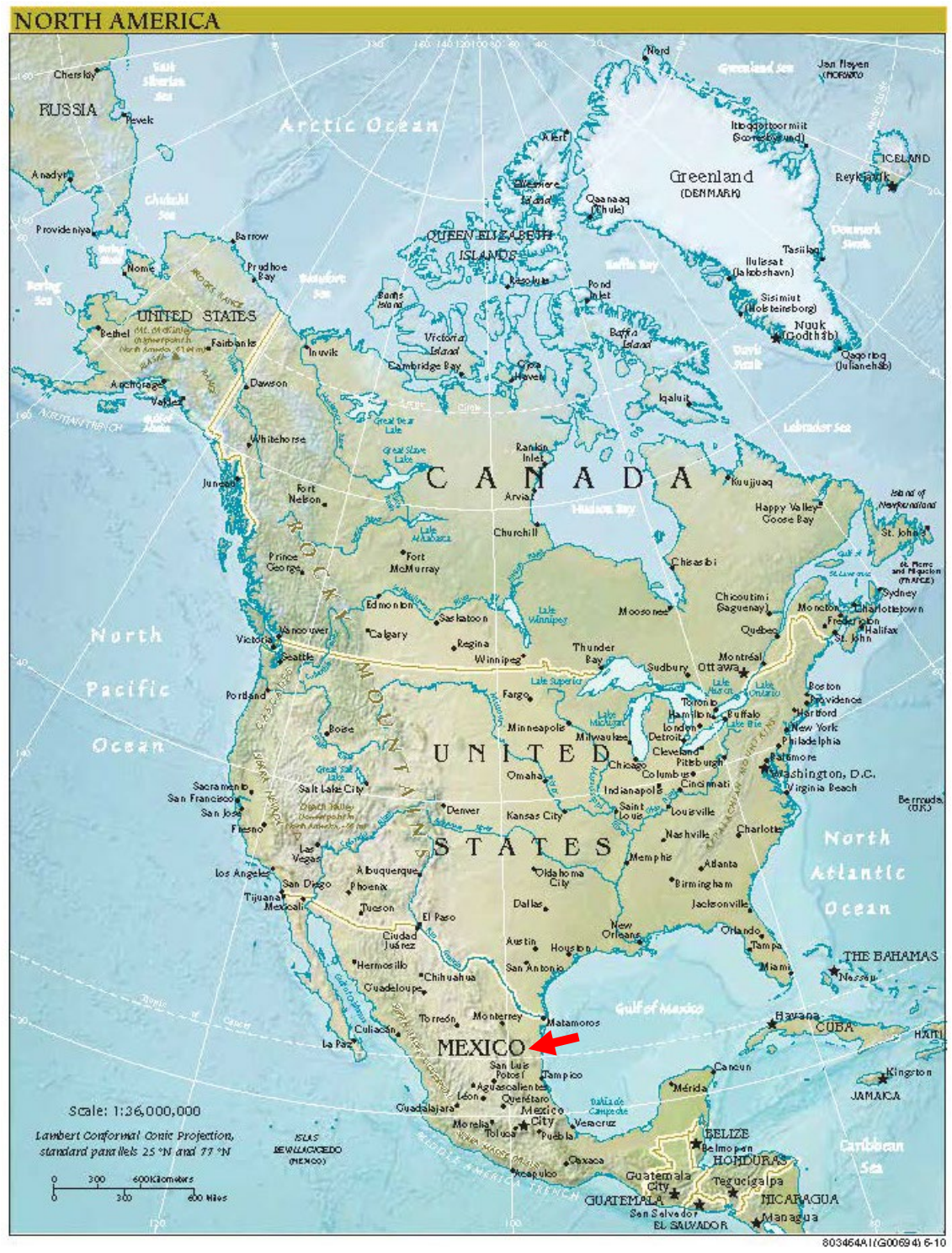

Figure 7. Country of Mexico, North America. Map courtesy of University of Texas at Austin. http://legacy.lib.utexas.edu/maps/americas/north_america ref_2010.pdf. The red arrow points to the country of Mexico.

Despite these ideal foundations, REDD + still had its issues. Carbon credits were never fully ideated from the start and so remained nebulous. A central question remained whether or not the sale of such credits, which represented an 
emissions reduction relative to an agreed-upon baseline of carbon dioxide emissions, would be sufficient to cover the cost to the community of hitting such reduction benchmarks (Borrego 2014). Additionally, the value of such reduction benefits would not be realized if the conservation actions needed to meet those goals took the place of more profitable land use (Borrego 2014).

Other REDD+ issues include the fact that in many communities, the program targets state-owned forests because of the ease of navigating land owner relations, but indigenous and local community advocacy organizations argue that if REDD+ programs more frequently look to target state owned forests, they will disenfranchise users with unrecognized rights to those forests, which could prevent those populations for whom economic benefits are intended from benefitting from payments at all (Mahanty 2013). This would compound the cost of forest protections on those groups (Mahanty 2013). Researchers have suggested that REDD+ schemes should first seek then to support low income and indigenous communities in reorganizing tenure relations in order to more frequently target that land before attempting to organize payment structures on state-owned land (Corbera et al. 2011).

Buy-in from all members in a community is crucial because there are unintended consequences for non-participants, such as price inflation to purchase land and the loss of access to resources (Mahanty 2013). Some communities have seen greater success from REDD+ programs as well as increased improvement in livelihood when intentional community forest management programs are implemented concurrently with REDD+ (Skutsch 2013), but the expertise and effort needed to run both efforts simultaneously may be another barrier to success, and, since participation is voluntary, soliciting full participation from any one community can prove difficult (Corbera et al. 2011).

Government structures and oversight in some REDD+ communities are not becoming involved to the level of need, leaving unclear procedures for how to involve some communities such as indigenous peoples. Additionally, many strategies do not have clear policies on who is entitled to corresponding benefit streams from forest carbon (Corbera et al. 2011). Evaluations suggest that assigning carbon credits at the community level is difficult since the credits don't always function in the ways in which they are intended to, and because payments based on performance assessment are often inefficient and not equitably distributed. Flat rate payments could be easier to administer, as could increases in carbon stock. Skutch(2013) study suggests that classifying reduced deforestation and degradation as ecosystem services could then allow governments to assign debits to communities achieving environmental goals, thereby allowing the government to use those as credits to make payments directly to communities that improve their overall forest management (Skutsch 2013).

One other issue with REDD+ is that it's not always the case that areas of high biodiversity, poor communities, and areas with high resources are one in the same, and therefore it is likely that trade-offs will have to occur between selecting a site 
with a high rate of poverty verses a site that has the greatest and most immediate threat of deforestation (Mahanty 2013). It also has to be anticipated that some degradation of the forest that will occur, because if a conservation area is identified that is inhabited by poor communities but has little resources, a REDD+ program would not assist in lifting that community out of poverty since the sale of ecosystem services wouldn't generate enough income (Mahanty 2013). Other issues with REDD+ include paperwork; the time and effort needed to negotiate and sign contracts to establish REDD+ and other PES's is prohibitive, as well as funding, time, and often physical labor planting trees and such needed up front by poor communities to begin their participation in REDD+ (Mahanty 2013).

Results remain mixed and REDD+ on the whole is woefully under-evaluated; one study reported that despite having REDD+ programs in place for the past three decades, deforestation had not decreased significantly. Mexico from 19762000 had one of the world's highest deforestation rates, an average of 545,000 hectares per year, and that rate has not decreased much. As with other such PES schemes, it is difficult, especially with a dearth of hard data, to attribute any reforestation or emissions reduction successes to REDD+ and not to other inadvertent circumstances (Duchelle 2018).

Ultimately, while REDD + is based on sound land rights policies, it needs additional thought in regards to proper management, a full evaluation of the tradeoffs and costs of the program, and local participation needs to be boosted to fully realize the benefits of such a communal program.

\section{Discussion}

This high-level comparative evaluation of these four case studies; RFFP in China, PES in Rwanda, CAMPFIRE in Zimbabwe, and REDD+ in Mexico reveals successes but also several shared programmatic issues.

The first issue is concerned with land rights and ownership. Formal ownership of between $65 \%$ and $75 \%$ of forests located in developing countries are owned and managed not by communities but by governments (Corbera et al. 2010). This is not ideal for effective management of payment for ecosystem services and similar models as it does not allow producer communities to make the best choices for the management of their land. It centers power in the hands of local and national governments, which often corrupt the conservation program to keep payments in their own pockets, rather than passing the revenue along to the producer communities.

In Zimbabwe, for example, the communal land tenure model has resulted in a legal disagreement between private farmers and communal land farmers, which has tempted some local councils to appropriate the revenues garnered from wildlife management activities for their own purposes rather than appropriately distributing them to the producer communities (Murphee 2014). In Rwanda, where there is no governmental land registration system, pockets of land have no documented ownership claim and farmers essentially squat on the land to cultivate 
it. When a community seeks to start a PES system, they need to first expend significant amounts of time and resources documenting who actually owns the land before even putting a PES program in place (Willetts 2008).

It may not be absolutely necessary for a community to own land rights to the land in which they derive livelihood from, but some form of ownership is needed. Communal land agreements, which encompass both property rights and more informal agreements that define resource access, may be more ideal models for successful implementation of conservation and development strategies.

Traditional tenure agreements are often complicated, characterized by competing claims on rights to access as well as competing directions on how resources should be managed and who should be included and excluded in such agreements (Corbera et al. 2010). Therefore, agreements governing benefits from and access to natural resources should not be grounded in such inflexible and complicated schemes but should rather look to other novel and innovative methods of authority (Corbera et al. 2010).

Part of the success of Mexico's REDD+ program can be attributed to the fact that much of the country's arable land is owned by the communities and the indigenous communities that farm and derive services from it. Land that contains agrarian communities and is owned and managed by ejidos ("a group of families that claim rights over a territory to which, for example, they migrated to") represent $52 \%$ of the agrarian landscape in Mexico (Corbera et al. 2011).

Another complication involved in land ownership involves the fact that claims to the land do not equate to claims over the ecological products that the land creates. The Mexican Forest Law of 1942 put forest resources in the hands of industrial development, leaving poor communities only able to sell their timber to those companies or being prohibited from utilizing ecosystem services and resources at all. The industrial development companies, in turn, imposed heavy restrictions on those poor communities and because payments were routed through state agencies, they often never reached the producer communities or individuals to whom they were owed. This resulted in a situation where communal forest rights were ambiguous at best and the state gained most of the financial benefit from the harvesting of forest resources (Corbera et al. 2011).

Another high-level issue shared between the programs described in this paper is that of poor government oversight and ineffective management policy.

China's RFFP programs attribute some local failures to the fact that the programs are most often managed by the state government, which over-emphasize quick results, visible improvement, and measurable performance targets, rather than using benchmarks and performance targets on a more appropriate scale for the time and effort that it takes to turn around an entire ecosystem. The RFFP programs are often judged by their ability to promote the careers of the bureaucrats involved in their management and their ability to hit fiscal targets, instead of focusing on forest regrowth. While the RFFPs mostly meet the national criteria established- to date, all RFFPs in China have collectively reforested 28.9 
million hectares, some local programs, such as those in Baiwu and Caoxiu, reported no additional forest cover or were plagued by illegal tree harvest, but their results were lost in the roll-up to national-level data (Trac et al. 2012).

In Mexico, REDD+ programs have struggled with weak policies governing access to benefits from forest carbon which has caused confusion and left producer communities with smaller or nonexistent revenue streams.

In Zimbabwe, political unrest almost brought the CAMPFIRE program to a halt when funding and support from the government and donor groups halted, and a similar situation could arise in Rwanda. The effects of this political unrest could have been alleviated with policy interventions that empowered the producer communities themselves to be more involved in decision-making at the highest levels (Tchakatumba 2019). A study by Mapedza (2009) suggested that the government be cut out of revenue management, allowing actors directly involved with purchasing the ecosystem services to connect directly with producer communities.

A more appropriate role for governments could be to invest in building stronger infrastructure around such conservation programs as well as investing in scientific institutions and conservation- related supply chains (Pingali et al. 2010). Policies should govern community empowerment and involvement to ensure that involvement is equitable and genuine.

Another shared issue exists in the interplay between conservation and livelihood. Many poor farmers rely on their crops not only for livelihood but for subsistence, and so when their land is marked for conservation purposes, they risk the loss of subsistence. This has occurred in Zimbabwe and in Mexico. In these cases, it's important to understand the dynamics and needs of the communities that rely or relied on those areas for subsistence, livelihood or cultural value (which are all defined ecosystem services) and ensure that their needs can be met elsewhere. Otherwise, they should have the opportunity to earn enough revenue from such programs or from agriculture to maintain their livelihood, or conservation programs run the risk of sending already marginalized communities spiraling further into poverty.

In these high-poverty, high subsistence farming locations, ecosystem services models may be more appropriate than PES systems such as REDD+ due to the PES programs' imposition of restrictions on land usage within local forests, which massively impacts low-income populations whose well-being is crucially dependent on forest resources. Behavioral changes for sustainable ecosystem management are unlikely to follow from such restrictive models, and alternatives to forest resources would rarely be affordable for low-income households (Barlow et al. 2007).

\section{Conclusion}

RFFP in China, PES in Rwanda, CAMPFIRE in Zimbabwe and REDD + in Mexico are four examples of structures aiming to improve both the health of the 
environment while improving the livelihood of the poor populations that rely on their native ecosystems for subsistence and other ecological services. These programs are doing a lot of good in improving both targets, but share issues of poor program management, lack of effective government oversight, lack of community empowerment, and ineffective land ownership models.

A future program with similar goals of improving conservation and lifting communities out of poverty could build on these programs. Specifically, such a program could utilize the communal land structure in REDD+ that allows communities to make the best ecological and livelihood decisions on their land. It could build the value of ecosystem services into its national economy, as accomplished by CAMPFIRE and Rwanda's PES. It could pay poor communities to improve the land on which they live, as did China's RFFP.

Any such program should build on these successes while also building strong program infrastructure that includes community involvement at all levels, especially in executive decision making. It should regulate government oversight of program management while also limiting the role of government in the management of payments to producer communities or create a watchdog group that ensures payments are getting to those communities in full. It should carefully evaluate programmatic data and build performance targets that fully grasp the value of ecosystem services to conservation targets and to the livelihood of poor communities. When planting in conservation areas, it should communicate with producer communities and plant a diversity of native species that best assists those communities in management and subsistence. Finally, such a program should evaluate land ownership models to ensure that land tenure is supporting communities in making the best decisions for their land.

Acknowledgments

Five reviewers offered suggestions that improved this paper.

\section{Literature Cited}

Abubakari, M., K. O. Twum, and G. A. Asokwah. 2020. From conflict to cooperation: The trajectories of large scale land investments on land conflict reversal in Ghana. Land Use Policy 94. 104543. https://doi.org/10.1016/j.landusepol.2020.104543

Agrawal, A. and A. Angelsen. 2009. Using community forest management to achieve REDD+ goals. pp. 201-212. In, Angelsen, A., with M. Brockhaus, M. Kanninen, E. Sills, W. D. Sunderlin, and S. Wertz-Kanounnikoff. Realizing REDD+: National Strategy and Policy Options. Center for International Forestry Research. Denmark. 361 pp. Retrieved from: https://www.cifor.org/publications/pdf files/Books/BAngelsen0902.pdf

Alcamo, J., N. J. Ash, C. D. Butler, J. B. Callicott, D. Capistrano, S. R. Carpenter, J. C. Castilla, R. Chambers, K. Chopra, A. Cropper, G. C. Daily, P. Dasgupta, R. de Groot, T. Dietz, A. K. Duraiappah, M. Gadgil, K. Hamilton, R. Hassan, E. F. Lambin, L. Lebel, R. Leemans, L. Jiyuan, J.-P. Malingreau, R. M. May, A. F. McCalla, T. (A. J.) McMichael, B. Moldan, H. Mooney, S. Naeem, G. C. Nelson, W.-Y. Niu, I. Noble, Z. Ouyang, S. Pagiola, D. Pauly, S. Percy, P. Pingali, R. Prescott-Allen, W. V. Reid, T. H. Ricketts, C. Samper, R. (B.) Scholes, H. Simons, F. L. Toth, J. K. Turpie, R. T. Watson, T. J. Wilbanks, M. Williams, S. Wood, S. Zhao, M. B. Zurek (and other contributing authors, etc.). 2003. Ecosystems and Human Well-being: A Framework for Assessment. A Report of the Conceptual Framework Working Group of the Millennium 
Ecosystem Assessment. Island Press. Washington, District of Columbia, USA. 245 pp. http://pdf.wri.org/ecosystems_human_wellbeing.pdf

Ali, N., X. Hu, and J. Hussain. 2020. The dependency of rural livelihood on forest resources in northern Pakistan's Chaprote valley. Global Ecology and Conservation. 22(e01001). 11 pp. https://doi.org/10.1016/j.gecco.2020.e01001

Alkire, S., M. Chatterje, A. Conconi, S. Seth, and A. Vaz. 2014. pp. 1-4. In, Poverty in rural and urban areas: Direct comparisons using the global MPI 2014. OPHI Briefing 24. University of Oxford. Oxford, England, UK. 4 pp. https://doi.org/10.35648/20.500.12413/11781/ii020

Barlow, J., T. A. Gardner, I. S. Araujo, T. C. Ávila-Pires, A. B. Bonaldo, J. E. Costa, M. C. Esposito, L. V. Ferreira, J. Hawes, M. I. M. Hernandez, M. S. Hoogmoed, R. N. Leite, N. F. LoMan-Hung, J. R. Malcolm, M. B. Martins, L. A. M. Mestre, R. Miranda-Santos, A. L. NunesGutjahr, W. L. Overal, L. Parry, S. L. Peters, M. A. Ribeiro-Junior, M. N. F. da Silva, C. da Silva Motta, and C. A. Peres. 2007. Quantifying the biodiversity value of tropical primary, secondary, and plantation forests. Proceedings of the National Academy of Sciences of the United States of America 104:18555-18560. https://doi.org/10.1073/pnas.0703333104

Borrego, A. and M. Skutsch. 2014. Estimating the opportunity costs of activities that cause degradation in tropical dry forest: Implications for REDD+. Ecological Economics 101:1-9. https://doi.org/10.1016/j.ecolecon.2014.02.005

Brandt, J. S., T. Kuemmerle, H. Li, G. Ren, J. Zhu, and V. C. Radeloff. 2012. Using Landsat imagery to map forest change in southwest China in response to the national logging ban and ecotourism development. Remote Sensing of Environment 121:358-369.

https://doi.org/10.1016/j.rse.2012.02.010

Brundtland, G. H. 1985. World commission on environment and development. Environmental Policy and Law 14(1):26-30. https://doi.org/10.1016/S0378-777X(85)80040-8

Christiaensen, L. and L. Demery. 2007. Down to Earth: Agriculture and Poverty Reduction in Africa. The World Bank. International Bank for Reconstruction and Development. Washington, District of Columbia, USA. 122 pp. https://doi.org/10.1596/978-0-8213-6854-1

Clay, D. C. and L. A. Lewis. 1996. Land use, soil loss, and sustainable agriculture in Rwanda. pp. 271-287. In, Bates D. G. and S. H. Lees (Editors). Case Studies in Human Ecology. Springer Boston, Massachusetts, USA. 407 pp. https://doi.org/10.1007/978-1-4757-9584-4 12

Corbera, E. 2010. Mexico's PES-carbon programme: A preliminary assessment and impacts on rural livelihoods. pp. 54-81. In, Tacconi, L., S Mahanty, and H. Suich (Editors). Payments for Environmental Services, Forest Conservation and Climate Change: Livelihoods in the REDD. Edward Elgar Publishing Northampton, Massachusetts, USA. 288 pp. https://doi.org/10.4337/9781849806015.00009

Corbera, E. and K. Brown. 2010. Offsetting benefits? Analyzing access to forest carbon. Environment and Planning A: Economy and Space 42:1739-1761. https://doi.org/10.1068/a42437

Corbera, E., M. Estrada, P. May, G. Navarro, and P. Pacheco. 2011. Rights to land, forests and carbon in REDD: Insights from Mexico, Brazil and Costa Rica. Forests. 2(1):301-342. https://doi.org/10.3390/f2010301

Cronkleton, P., D. Bray, and G. Medina. 2011. Community Forest Management and the Emergence of Multi-Scale Governance Institutions: Lessons for REDD+ Development from Mexico, Brazil and Bolivia. Forests 2:451-473. https://doi.org/10.3390/f2020451

Dawson, N. and A. Martin. 2015. Assessing the contribution of ecosystem services to human wellbeing: A disaggregated study in western Rwanda. Ecological Economics 117:62-72. https://doi.org/10.1016/i.ecolecon.2015.06.018

Duchelle, A. E., G. Simonet, W. D. Sunderlin, and S. Wunder. 2018. What is REDD+ achieving on the ground? Current Opinion in Environmental Sustainability 32:134-140. https://doi.org/10.1016/j.cosust.2018.07.001

Fan, S., L. Zhang, and X. Zhang. 2004. Reforms, investment, and poverty in rural China. Economic Development and Cultural Change 52:395-421. https://doi.org/10.1086/380593Firoozjaie, N. A., M. Ghadami, and M. G. Jooybari. 2019. An investigation of tourism impact on urban and rural land use pattern changes (a case study: Kelardasht County). Journal of Studies of Human Settlements Planning 14:395-410. http://jshsp.iaurasht.ac.ir/article_667746 en.html 
Frost, P. and I. Bond. 2008. The CAMPFIRE programme in Zimbabwe: payments for wildlife services. Ecological Economics 65:776-787. https://doi.org/10.1016/j.ecolecon.2007.09.018

Fukuda-Parr, S., N. Birdsall, J. Sachs, S. Bonacito, E. Boudard, C. De Gregorio, H. Fu, C. Johansson, C. Kuonqui, S. Mehrotra, T. Mukhopadhyay, O. Noman, S. Pettinato, D. Stewart, A. Talib, N. Terrell, E. White. 2003. Human Development Report 2003. Millennium Development Goals: A Compact Among Nations to End Human Poverty. United Nations Development Programme (UNDP) and Oxford University Press. New York, NY, USA. 367 pp. http://hdr.undp.org/sites/default/files/reports/264/hdr 2003 en complete.pdf

Gao, Y., Z. Liu, R. Li, and Z. Shi. 2020. Long-Term Impact of China's Returning Farmland to Forest Program on Rural Economic Development. Sustainability 12: 1-17. https://doi.org/10.3390/su12041492

Jordan, R. 2017. Stanford scholars examine ecological underpinnings of rural poverty. Stanford | News. Retrieved on June 17, 2020 from https://news.stanford.edu/2017/07/14/understandingpoverty-traps/

Karangwa, C. 2011. Payment for ecosystem services for social welfare enhancement at community level, the case of Rwanda. pp. 132-175. In, Mogaka, H., J. Okeyo-Owuor, and A. Kipkoech (Editors). Case Studies from Eastern and Central Africa. Association for Strengthening Agricultural Research in Eastern and Central Africa (ASARECA). Entebbe, Uganda. https://bit.ly/31mg3z3

Khan, A. R. 1999. Poverty in China in the period of globalization: New evidence on trend and pattern. Discussion paper No. 22. Issues in Development, International Labour Office. Geneva, Switzerland. $58 \mathrm{pp}$. https://pdfs.semanticscholar.org/30b0/dc3fb5552d94eed437fc61f8f212b829f5fd.pdf

Knausenberger, W., G. Booth, C. Bingham, and J. Gaudet. 1996. Environmental Guidelines for SmallScale Activities in Africa, Environmentally Sound Design for Implementing Humanitarian and Development Activities. United States Agency for International Development (USAID). Technical Paper No. 18. 200 pp.

Lewis, L. A., and L. Berry. 2012. African Environments and Resources. Taylor and Francis. Oxford, United Kingdom. 420 pp.

Li, R., H. Zheng, C. Zhang, B. Keeler, L. Samberg, C. Li, S. Polansky, Y. Ni, and Z. Ouyang. 2020. Rural household livelihood and tree plantation dependence in the central mountainous region of Hainan island, china: Implications for poverty alleviation. Forests 11; 248. https://doi.org/10.3390/f1 1020248

Logan, B. I. and W. G. Moseley. 2002. The political ecology of poverty alleviation in Zimbabwe's Communal Areas Management Programme for Indigenous Resources (CAMPFIRE). Geoforum 33(1):1-14. https://doi.org/10.1016/S0016-7185(01)00027-6

Mahanty, S., H. Suich, and L. Tacconi. 2013. Access and benefits in payments for environmental services and implications for REDD+: Lessons from seven PES schemes. Land Use Policy 31:38-47. https://doi.org/10.1016/j.landusepol.2011.10.009

Manyena, S. B., A. E. Collins, F. Mudimba, and D. Mudimba. 2013. "Are You Serious to Ask Me about Who Owns Wildlife?" Politics of Autonomy over Wildlife Resources in the Zambezi Valley, Zimbabwe. Forum for Development Studies 40:87-109. https://doi.org/10.1080/08039410.2012.688862

Mapedza, E. 2009. Decentralisation outcomes in the context of political uncertainty in Zimbabwe: a comparative assessment from co-management and CAMPFIRE and implications for policy. pp. 215-333. In, German, L., A. Karsenty and A. Tiani (Editors). Governing Africa's Forests in a Globalized World. Earthscan. London, England, UK. 392 pp. [This paper was presented in Workshop on Forest Governance \& Decentralization in Africa. 8-11 (April 8-11, 2008). Durban, South Africa. https:/www.cifor.org/publications/pdf files/events/documentations/durban/papers/Paper26Mapedza.pdf ]

Milder, J., S. Scherr, and C. Bracer. 2010. Trends and future potential of payment for ecosystem services to alleviate rural poverty in developing countries. Ecology and Society 15(2):4. https://doi.org/10.5751/ES-03098-150204, http://www.ecologyandsociety.org/vol15/iss2/art4/

Murphree, M. W. 2014. Communal land wildlife resources and rural district council revenues. CASS Occasional Paper Series (Centre for Applied Social Sciences, Institute of Development Studies, 
Centre for Applied Social Sciences. Harare, Zimbabwe). Number - 51/931-10. https:/opendocs.ids.ac.uk/opendocs/handle/20.500.12413/4624

Murombedzi, J. C. 1999. Devolution and stewardship in Zimbabwe's CAMPFIRE programme. Journal of International Development 11(2):287-293.

https://doi.org/10.1002/(SICI)1099-1328(199903/04)11:2<287::AID-JID584>3.0.CO;2-M

Nkuba, M. R., R. Chanda, G. Mmopelwa, E. Kato, M. N. Mangheni, and D. Lesolle. 2020. Influence of indigenous knowledge and scientific climate forecasts on arable farmers' climate adaptation methods in the Rwenzori region, western Uganda. Environmental Management 65:500-516 https://doi.org/10.1007/s00267-020-01264-x

Phelps, J., E. L. Webb, and A. Agrawal. 2010. Does REDD+ threaten to recentralize forest governance? Science (American Association for the Advancement of Science. Washington, District of Columbia, USA) 328(5976):312-313. https://doi.org/10.1126/science.1187774

Pingali, P. 2001. Population and technological change in agriculture. pp. 11742-11744. In, Smelser, N. J. and P. B. Baltes (Editors). International Encyclopedia of the Social and Behavioral Sciences. Elsevier Science Ltd. Oxford, England, UK. 17,500 pp. https://doi.org/10.1016/B0-08043076-7/04158-9

Pingali, P. 2010. Agriculture renaissance: making "agriculture for development" work in the $21 \mathrm{st}$ century. Chapter 74, pp. 3867-3894. In, Pingali, P. L. and R. E. Evenson (Editors). Handbook of Agricultural Economics. Volume 4. Macroeconomics, Macrosectoral Policies, and Agriculture in Developing Countries. Elsevier BV. Amsterdam. The Netherlands. 3,894 pp. https://doi.org/10.1016/S1574-0072(09)04074-2

Popovych, A. 2017. Social-economical and agro-ecological issues of rural poverty. Annals - Economy Series, Constantin Brancusi University, Faculty of Economics 1:13-26. http://www.utgjiu.ro/revista/ec/pdf/2017-01.Volumul_1_Special/02_Popovych.pdf

Ravallion, M. and S. Chen. 2004. China's (Uneven) Progress Against Poverty. The World Bank. World Bank, Washington, District of Columbia, USA. 57 pp. http://doi.org/10.1596/18139450-3408

Redford, K. H. and W. M. Adams. 2009. Payment for ecosystem services and the challenge of saving nature. Conservation Biology 23:785-787. https://doi.org/10.1111/j.1523-1739.2009.01271.x

Reid, W., H. Mooney, A. Cropper, D. Capistrano, S. Carpenter, K. Chopra, K., R. Hassan, T. Deitz, P. Dasgupta, R. Kasperson, R. Leemans, R. May, A. McMichel, P. Pingali, C. Samper, R. Scholes, R. Watson, A. Zakri, Z. Shidong, N. Ash, E. Bennett, P. Kumar, M. Lee, C. RaudseppHearne H. Simons, J. Thonell, M. Zurek. 2005. Ecosystems and Human Well-Being. Island Press. Washington, District of Columbia, USA. 137 pp.

Reyers, B., D. J. Roux, and P. J. O'Farrell. 2011. Can ecosystem services lead ecology on a transdisciplinary pathway? Environmental Conservation 37:501-511. https://doi.org/10.1017/S0376892910000846

Rosa, M. F., C. A. Bonham, J. Dempewolf, and B. Arakwiye. 2016. An integrated approach to monitoring ecosystem services and agriculture: Implications for sustainable agricultural intensification in Rwanda. Environmental Monitoring and Assessment 189(1, Article 15):1-35. https://doi.org/10.1007/s10661-016-5607-6

Sikor, T., A. Martin, J. Fisher, and J. He. 2014. Toward an empirical analysis of justice in ecosystem governance. Conservation Letters 7:524-532. https://doi.org/10.1111/conl.12142

Sikor, T., J. Stahl, T. Enters, J. C. Ribot, N. Singh, W. D. Sunderlin, and L. Wollenberg. 2010. REDDplus, forest people's rights and nested climate governance. Global Environmental Change 20(3):423-425. https://doi.org/10.1016/j.gloenvcha.2010.04.007

Skutsch, M., A. Borrego, L. Morales-Barquero, J. Paneque-Gálvez, M. Salinas-Melgoza, M. I. Ramírez, D. Perez-Salicrup, D. Benet, S. Monroy, and Y. Gao. 2015. Opportunities, constraints and perceptions of rural communities regarding their potential to contribute to forest landscape transitions under REDD+: Case studies from Mexico. International Forestry Review 17(Supplement 1):65-84. https://doi.org/10.1505/146554815814669025

Tchakatumba, P. K., E. Gandiwa, E. Mwakiwa, B. Clegg, B and S. Nyasha. 2019. Does the CAMPFIRE programme ensure economic benefits from wildlife to households in zimbabwe? Ecosystems and People 15. 119-135. 
https://doi.org.10.1080/26395916.2019.1599070

Thompson, M. C., M. Baruah, and E. R. Carr. 2011. Seeing REDD+ as a project of environmental governance. Environmental Science \& Policy 14:100-110. https://doi.org/10.1016/j.envsci.2010.11.006

Trac, C. J., A. H. Schmidt, S. Harrell, and T. M. Hinckley. 2013. Environmental reviews and case studies: Is the returning farmland to forest program a success? Three case studies from Sichuan. Environmental Practice 15:350-366. https://doi.org/10.1017/S1466046613000355

Von Braun, J. and F. W. Gatzweiler. 2014. Marginality - An overview and implications for policy. In, Von Braun, J. and F. W. Gatzweiler (Editors). pp. 1-23. Marginality. Springer. Dordrecht, The Netherlands. 389 pp. https://doi.org/10.1007/978-94-007-7061-4_1

Willetts, E. 2008. Watershed Payments for Ecosystem Services and Climate Change Adaptation Case Study on Rugezi Wetlands, Rwanda. MSc Project. Nicholas School of the Environment and Earth Sciences, Duke University. Durham, North Carolina, USA. 71 pp. https://dukespace.lib.duke.edu/dspace/handle/10161/469

Wunder, S. 2008. Payments for environmental services and the poor: concepts and preliminary evidence. Environment and Development Economics 13:279-297. https://doi.org/10.1017/S1355770X08004282

Zhang, Y. and G. Wan. 2006. The impact of growth and inequality on rural poverty in China. Journal of Comparative Economics 34:694-712. https://doi.org/10.1016/j.jce.2006.08.008

Zang, Y., Y. Liu, Y. Yang, M. Woods, and F. Fois. 2020. Rural decline or restructuring? implications for sustainability transitions in rural China. Land Use Policy 94.104531. $11 \mathrm{pp.}$ https://doi.org/10.1016/j.landusepol.2020.104531

Zinda, J. A. and Z. Zhang. 2019. Explaining heterogeneous afforestation outcomes: How community officials and households mediate tree cover change in China. World Development 122:385398. https://doi.org/10.1016/j.worlddev.2019.05.020 